and properly arranged to become admirable educational aids. In few, however, is there enough material to engage the whole time and attention of an able man in taking care of it; indeed a single month devoted to each of the departments of zoology, botany, geology, and so forth, would suffice, and, in many cases, more than suffice, to put each into working order to begin with, and after the first arrangement it would be easy enough to maintain the efficiency of each collection and to add what fresh acquisitions might be made in the course of a week's visit once a year.

Let, then, an association of the younger workers in the various branches of science be formed in London, under the direction of a committee of well-known names, and let it offer to send out every year for short intervals, to such museums as should be ready to pay for them, botanists, zoologists, geologists, and the rest, to name and arrange their several collections ; each member so dispatched would then visit several museums in succession, confining his attention in each to the collection made in his own subject, and each museum would be visited by several members, one member for each of its essentially different collections. Thus for a slight expense (payment on the piece-work system) a large number of our Local Museums would be put under the curatorship of a group of specialists, and so be brought into efficient and permanent working order. The idea is simply that of visiting curatorships supplied on the principle of co-operation, and made possible by the facilities for travelling afforded by our modern railway system.

It can scarcely be doubted that in the summer, when lectures and lecturing are over, many scientific men might be found willing and able to undertake the task.

\section{Rainbow Reflected from Water}

MR. CROOKES' interesting observation of the reflection of a rainbow-described in his letter in NATURE, August 16-is easily reproduced, on a small scale, experimentally.

I fixed a "spreader" to the nozzle of a garden-engine so as to cause a shower of fine drops of water to spread in the sunshine. The segments of a bright primary rainbow and of a rather subdued secondary one stood out well-defined against the dark foliage of some trees, the remainders of the bows being lost against bright objects and sky behind.

At whatever point the bows were visible, I found that by placing a mirror or blackened glass wetted so as to form a surface of water, in place of the eye, and then observing from a fresh point, the reflections of both bows could be very distinctly seen at the same time that real bows were also visible.

The reflected bows were al ways apparently smaller in diameter than the real bows which were visible at the same time from the same position. The reason of this is, I presume, that the bows seen in the mirror are not the reflections of the bows visible, at the same time to the eye, but of bows which the eye would see if it occupied the place of the mirror, or rather of that portion of it which is observed. When, for instance, the mirror is one yard below the level of the eye, the drops by which the bows are formed that are reflected by the mirror. are necessarily about one yard below the corresponding drops by which the direct bows seen by the eye are formed; in other words the direct bows are one yard above the bows which are actually reflected. Therefore, when both are cut by a common horizontal line formed by the surface of the mirror, a reflected bow must be the more shortened of the two and its diameter apparently reduced.

I would suggest that this may be the explanation of the displacement of the colours where the real and reflected bows met, which Mr. Crookes observed.

Hampton Wick, August 20

\section{The Greenland Foehn}

DANS le dernier numero (406) de votre journal je vois que vous m'avez fait l'honneur de donner un abstract d'un petit travail sur le foehn du Groenland. Malheureusement le rapporteur n'a pas bien compris le danois (ou le norwegien) en quelques endroits, et je me permettrai de vous indtquer les méprises suivantes comme les plus dangereuses.

2ième alinéa. - "Dr. Pfaff has carried on .... and these show that the average temperature of February, 1872, was $-8^{\circ} .7 \mathrm{C}$, and of February, $1863-3^{\circ} 1^{\circ} 6$," etc. Les deux mots, "February," sont omis, ce qui fait croire que je parle de la tempćrature moyenne de l'anncé au lieu d'un mois.

5ième alinéa.- "These explanations go a great .... when at Jacobshavn shortly before $7 u l y, 9^{\circ} \mathrm{C}$. of heat are recorded." Au lieu de "July" j'ai dit "Christmas"; une température de $9^{\circ} \mathrm{C}$. est normale en juillet. Août 2r

\section{W. HOFYMEYER}

\section{On the Supposed Action of Light on Combustion}

IN answer to Mr. Watson's inquiry contained in your last number, I may state that at the meeting of the Brish Association at Exeter, in 1869 , I read a paper unter the above title (See Phil. Mag. for September, 1869), in which some comparative experiments were made on candles burning in full sunshine and also in a darkened closet. This mode of experiment was adopted because it allowed the results to be tested by weighing. Candles of the same make were used and hard sperm candles preferred as being less affected by variations of temperature than composite. The candles were allowed to burn during four hours. I give one result :-

In the dark (temp. $8 \mathrm{r}^{\circ} \mathrm{F}$.) each candle lost 544 grains, or I 36 grains per hour.

In the light (temp. $84^{\circ}$ ) each candle lost 567 grains, or $1_{42}$ grains per hour nearly.

It is evident that in this case the increase of temperature caused by the bright sunshine led to an increased consumption of material, but the general result was that light has no retarding influence on combustion.

Highgate, August 25

C. TOMLINSON

\section{Evolution by Leaps :}

WITH reference to an article entitled "Evolution by Leaps," in your "Biological Notes" (NATURE, vol. xvi. p. 208), I would call attention to a fact which is not unknown to horticulturists, that a hybrid sometimes proclaims its origin by producingeven on the same rachis-flowers and fruits, some of which resemble one parent and some the other.

Many a time I have plucked a branch of two or three feet in length from a pear-tree growing in a village in Kent, which bore at the proximal end pears of a certain size and description, and on the terminal twigs pears smaller in size, of a different flavour, and later in blooming and ripening.

As this "sport" prevailed throughout the tree, which was large and flourishing, there was no possibility of its being the result of a direct graft.

lseddington Park

PaUl HENRY STOKUI

\section{$Z$ ygœna Filipendulx}

In July last I was breeding some $Z$ ygana flipendulce (six-spot Burnet moth) from pupæ taken in a chalk-pit near Cambridge, one of which was developed into a moth with five wings; four of these correspond to the normal wings in this species and are perfect in every respect, as also are five of the legs. The sixth leg (a hind leg) is absent, its place being filled up by the extra wing, which springs from the exact point at which the missing leg would naturally join the body. In appearance the extra wing resembles the ordinary hind wing of the species, but is only about half its usual size. It is of a yellowish-red tinge, and not so thickly covered with scales as the other wings of the insect. Of the sixth leg there is no external trace whatever, as far as I can see ; in fact it would seem at first sight as if the leg had, by some means or other, been transformed into a wing.

This moth is subject to a good deal of variation as regards the size of the spots on the fore-wings, two of which are occasionally united; also, in this particular locality, the red colour is replaced by yellow in about I per cent. of the specimens. The chalk.pit to which I have alluded is scarcely an acre in extent, and as the species does not seem to occur elsewhere in the immediate neighbourhood, continuous interbreeding must have been going on for a long time.

I have never met with or heard of such a curiosity of morphology either in this or any other lepidopterous species before, but some of your readers will doubtless be able to adduce other instances of a similar nature.

Clare College, Cambridge, August 2 r

\section{Drosera}

I REC to enclose a photograph of a specimen of Drosera rotundifolia found by me at the lickey Hills on July $\mathrm{I}$ this year. 